\title{
Research on the Application of Modern Education Technology in E - business Teaching
}

\author{
Runhong Peng \\ Institute of Information Technology of GUET, Guilin 541004, China \\ merryprh@126.com
}

Keywords: Modern Education Technology; E-business; Application

\begin{abstract}
With the development of computer and network technology, e-business has increasingly become an important part of various business activities. The modern education technology is applied to e-business courses teaching, optimize education effect by multi-channel and multi-mode teaching, cultivate high-quality skilled talent to meet the needs of the society. E-business teaching should actively strengthen the spread and application of modern education technology, through the scientific use of modern technology, so that the classroom teaching and management process has been effectively improved and optimized to innovate the school's education model. E-business teachers should actively use modern education technology to design, develop and utilize all teaching resources, explore more innovative and scientific teaching model, so that the current status of e-business teaching could be effectively improved.
\end{abstract}

\section{Introduction}

With the rapid development of information technology and network economy, the global demand for e-commerce talents, e-commerce has become a hot topic of education. In the practice process of e-commerce teaching, making full use of modern education technology can not only be conducive to stimulate the e-commerce students' studying interest, promote students to learn efficiently, but also conducive to the establishment of exploratory, resource-based, collaborative learning model, provide an important guarantee for the virtual teaching model reform. In E-commerce teaching, we should make full use of modern education technology, highlighting the skills training and practical application, increase the proportion of practice teaching, to cultivate high-quality skilled talents with strong practical abilities, and quickly adapt to the needs of "e-commerce foundation work ".

\section{The inevitability analysis for the application of modern education technology to cultivate highly skilled talents}

Modern education technology is based on modern education ideology, theory and method, with system theory as guidance, with modern information technology as a means of education technology. It is a comprehensive embodiment of modern teaching design, modern teaching media and modern media teaching method, take aim at realizing the optimization of teaching process, teaching resources, teaching effect and teaching benefit. Modern education technology is the modern educational means and methods system which apply advanced education and teaching theory and scientific knowledge to the teaching practice. It makes full use modern information technology which takes computer as the core, achieve the improvement of teaching process by design, development, exploit, evaluation and management of teaching \& learning process and resource, make classroom teaching become elastic, flexible and agile, breaking the traditional teaching mode of "one blackboard one pen, a mouth for everybody listens ", establish autonomic, cooperative and exploratory learning style, which is significant for making full use of education resources, improving school efficiency, promoting education technology improvement and cultivating highly skilled talents. 


\section{The significance of modern education technology applied in e - commerce teaching}

Applying modern education technology in e-commerce teaching effectively, bring a new educational concept into the classroom teaching, to make profound reform of teaching content, methods, means, models and other aspects. Attractive and diverse teaching content and form can fully stimulate students' learning interest and motivation, so that students can more easily grasp the complex, boring knowledge, get better teaching results, and improve the quality of classroom teaching, and in the teaching process can also gradually build an initiative learning model with student-oriented, cultivate students to develop good self-learning habits, and then train more innovative talents.

\section{Strategy of modern education technology applied in e-commerce teaching}

(1) Establish teaching model with student-oriented. To actively establish teaching model focused on a teacher-dominated, student-centered, when teachers apply modern education technology, should perform teaching design with student-centered, guide students to actively explore the knowledge, take the initiative to find, take the initiative to participate in teaching practice; professional internship and practice is an indispensable way to improve the students' practical ability. School organizes students to participate in practical activities in the enterprises and institutions via holidays, during summer and winter holidays students choose their own enterprises, companies, shopping malls, offices, advertising companies and other business units according to their own interests and hobbies, engaged in secretarial, financial, personnel management, market development and market research, product publicity \& promotion and other activities.

Go deeper into society, contact with enterprises, enhance the perceptions for professional knowledge. Students are exposed to a wide range of corporate business practices, abstract knowledge of the book is applied to the actual work, build a sense of perception for own major, training students with theoretical ability, practical ability, innovation ability and learning ability, to stimulate students 'enthusiasm for learning; training students' awareness of collaboration, improving students' comprehensive ability and quality in all respects.

(2) Curriculum software used in teaching

The teaching simulation software in E-commerce provide common network service platform including business network, online mall, online payment and others, to achieve several types of transactions such as B2B, B2C, C2C and online auction, the school can provide e-commerce system simulation software platform in the computer room for e-commerce simulation exercises. Through the exercise of manufacturers, logistics companies, consumers and other roles, let a number of students participate in the same system operation, through the mailbox application, digital certificate application / installation, EDI application, simulate to establish their own business or commercial seller website, online payment, delivery, site management and other operations, to complete the relevant business process learning. Exercises of E-commerce software and application platform facilitate the teachers and students to explore and discuss the specific issues in ecommerce activities; transactions simulation make students through e-commerce simulation operation to understand the whole process of business, more intuitive to master the steps and operations.

(3) Multimedia promote e-commerce teaching Multimedia is an advanced teaching method which is widely used in modern education. In traditional teaching, as for the abstract content which is difficult for the teachers to express and difficult to understand by student, the complicated change process, multimedia solves such problems by means of virtual animation technology and process demonstration. By sound, video, animation and other multimedia technology to increase the fun and vitality of courseware. Increasing the proportion of multimedia new technology in teaching can optimize the teaching, make effective use of classroom teaching time to improve teaching efficiency. CAI courseware, projection teaching audio and video, electronic textbooks, online exam, animation demonstration and others constitute digital, three-dimensional teaching materials, provide a full range of scientific and technological services for the curriculum. 
(4) Network practice improves students’ practical ability

Encourage students to participate in e-commerce activities in teaching, fully mobilize the students' curiosity, so that students learn and master the knowledge in practice. For example, when talking about online retail, guide students shopping in the real B2C (amazon joyo and etc) or C2C website (Taobao, eBay and etc), experience and understand the network transaction process. It is recommended to give e-commerce classes, require students to practice applying for registration by themselves at Taobao, to become a leaguer, handle with Alipay procedures, apply for their own web-mail, carry out a real online shopping, difficult problems occurred in above process can be published in the campus network, teachers and students communicate with each other in time, after class require the students by themselves to sum up the experience of mailbox application and online shopping for classroom discussion, so that students can understand e-commerce process more specific. The biggest advantage of online practice is to provide students with a real internship environment, not only increase the challenges of practical problem, but also gather experience for students to carry on network entrepreneurship in the future, help improve the students' e-commerce practical skills.

\section{Summary}

With the rapid development of social economy and technology, the comprehensive quality requirements from the society have gradually increased, and the overall optimization of modern education technology for education field has gradually been highlighted. For the college education institutions, the application of modern education technology is the inevitable requirement to iprove the cognitive efficiency of skills and knowledge level. At present, the application of domestic modern education technology in the field of education is still in the stage of development and improvement, need the exploration and innovation of every education worker, at the meanwhile of continuously improving the quality of e-commerce education, cultivate more outstanding skilled talents in line with the needs of social development.

\section{References}

[1]. Xin LIU, Fang HU, The Analysis of Modern Education Technology in Teaching Application of Financial Management Major, Higher Education of Social Science (2015) 32-36.

[2]. Chi-Hung Yeh, Gwo- Guang Lee, Jung-Chi Pai, using a technology-organization-environment framework to investigate the factors influencing e-business information technology capabilities, Information Development (2015) 435-450.

[3]. JINLIANG WANG, ZHAOQIAO DING, Exploration on the Teaching Mode of "Studio System” in E-Commerce Major of Higher Vocational Colleges, 2014 Asia_—Pacific Management and Engineering Conference (APME 2014), 2014-11-29.

[4]. Information on http://www.icetem.org 